\title{
Technika překonala všechny vzdálenosti, avšak nevytvořila žádnou blízkost
}

\author{
Michal Černý
}

Masarykova univerzita, Pedagogická fakulta, Katedra sociální pedagogiky

Epidemiologická reakce na covid-19 přinesla do edukace mnoho změn či podnětů, které zřejmě plně rozkryjeme a doceníme až později. Jedním z prvních hmatatelných důsledků byla technizace edukačního procesu. A to jak ve smyslu techniky jako jasně popsaného postupu, který slouží pro řešení jistých problémů, před které jsou studenti i vyučující postaveni, tak ve smyslu techniky jako arteficiální entity. Tyto dvě polohy technizace edukace spolu těsně souvisí - je to technika jako prostředek, která umožňuje „vzdělat se na dálku“ (distančně), ale také technika jako způsob uchopení této možnosti.

Citát Martina Heideggera, že „technika překonala všechny vzdálenosti, avšak nevytvořila žádnou blízkost", může být vnímaný jako jistý kritický povzdech, nebot' mnoho autorů a interpretů automaticky řadí Heideggera do proudu stojícího proti technice. Technika jako by byla něčím, co stojí mezi námi a světem, něčím, co z pedagogiky činní cosi, co není dostatečně blízké ani člověku, ale ani skutečnosti.

Domníváme se však, že takové čtení Martina Heideggera je poněkud nešt’astné či omezené. Jednak se vztahuje k určité historické etapě, která se k technice stavěla velice negativně. Vzpomeňme, že v témže textu se Heidegger jako k prŕkladu techniky uchyluje k atomové zbrani; jde o čas, který umožnil člověku spojit se s technikou ve dvou ničivých světových válkách (Heidegger, 1949), s nimiž měl Heidegger jistou životní zkušenost. Obě války byly právě technikou značně ovlivněné. Sociální prostředí nebylo pro dělníky v polovině

1 Ve skutečnosti jde o zkratku či parafrázi. Slovo technika vyplývá z Heideggerova textu, v němž se vztahuje ke svému vlastnímu výroku: „Toto kvapné odstraňování veškerých vzdáleností však nevytváří blízkost; nebot' nepatrná míra vzdálenosti není ještě blízkostí. Co nám film a rozhlas svým obrazem přiblížily na dosah ruky, může nám přesto zůstat vzdálené. Co leží v nedohlednu, může nám byt blízké. Malá vzdálenost není ještě blízkost. Velká vzdálenost není ještě dálka. Co je to blízkost, jestliže přesto, že i nejdelší vzdálenosti byly zkráceny na minimum, neustále uniká?" (Heidegger, 1993, s. 7). Sám Heidegger nabízí vlastní intepretaci problému, kterou si může čtenář snadno pročíst na následujících stranách výše citovaného díla. My se ale vypravíme jiným směrem, totiž propojíme jeho koncepty z přednášek Věda, technika a zamyšlení a Básnicky bydlí člověk s pragmatistickým pohledem akcentovaným v pedagogickém kontextu. 
dvacátého století stále zcela ideální, začínalo se rozvíjet ekologické smýšlení a zdálo se, že pro techniku není možné najít mnoho udržitelných argumentů, takže byla kritizována i Hannah Arendtovou (1996, 2009).

Rádi bychom ale tuto krátkou studii zaměřili jiným směrem, který je dle našeho soudu interpretačně podstatně zajímavější a který umožňuje Heideggerovu větu promýšlet ze zásadně odlišné perspektivy. Co je to technika? Technika označuje dva okrsky. První, technika je prostředek k určitým účelům. Druhý, technika je konání člověka. Oba přitom k sobě patří, nelze je od sebe oddělit (Heidegger, 2004a, s. 7). A přesto Heidegger tvrdí, že takové pojetí techniky je nesprávné nebo alespoň neúplné.

Německý filosof ve své přednášce Věda, technika a zamyšlení poměrně silně kritizuje techniku, respektive její pojetí jako prostředku pro uspokojování svých potřeb. Technika se podle něj stala něčím, co jsme začali užívat proti př́rodě. Bereme z přírody, drancujeme ji, a to vše jen proto, abychom se nemuseli o nic starat, abychom se měli lépe. Toto pojetí techniky samozřejmě nemusí být jediné, ale je vhodné si uvědomit, že nejde rozhodně o diskurs zanedbatelný (Heidegger, 2004a).

Abychom mohli odpovědět na otázku, co je to technika, nemůžeme se zaměřit na její instrumentální charakter, ale na její bytnost, na její nejvlastnější význam. Pokud by jím bylo jen ono obstarávání (Heidegger, 2018, s. 76-80) užitku, konformní konzumní smysl života, který nevede k autenticitě vlastního bytí, tedy k Pobytu, byla by výše uvedená kritika Heideggera vůči technice oprávněná. Naštěstí je ale možné postupovat dále ještě alespoň dvěma směry, které filosof navrhuje.

Tím prvním je technika jako nástroj k odhalování neskrytosti. U slova pravda můžeme vidět dva možné odstíny tohoto pojmu. Tím prvním je latinské veritas, pravda jako faktická danost, jako jistý soulad mezi přesvědčením a skutečností. Druhou možností je ale řecké slovo $\alpha \lambda \eta \dot{\eta} \theta \varepsilon ı \alpha$, které označuje neskrytost. (Heidegger, 2018, s. 248-266; Heidegger, 1993). $A \lambda \eta ́ \theta \varepsilon \iota \alpha$ není dopředu dána, ukazuje se člověku v procesu poznávání, záleží na jeho propozicích k vidění, ale i na situaci. $A \lambda \eta \dot{\eta} \theta \varepsilon \iota \alpha$ není statickou pravdou, ale něčím, co Heidegger navrhuje překládat jako neskrytost.

Technika je pak pro něj nástrojem, kterým lze k $\alpha \lambda \eta \dot{\theta \varepsilon \iota \alpha}$ (alétheia) přistupovat. Techniku jako takovou nelze odmítnout jako „vynález dáblův“, ale ani ji nekriticky adorovat. Je třeba ji vždy vnímat jako něco, co pomáhá člověku 
na cestě k odhalování neskrytosti (Heidegger, 2004a, s. 13). Toto odhalování je pak zjevně nejvlastnějším úkolem vzdělávání. Všechny školní předměty, jakkoli mohou být ve své struktuře a výuce silně kritizovány (Palouš, 2008), směřují právě $\mathrm{k}$ tomu, aby pomáhaly člověku $\mathrm{v}$ pohybu, $\mathrm{v}$ cestě, $\mathrm{v}$ jeho osobní změně, která se uskutečňuje v těsném kontaktu s technikou prostřednictvím $\alpha \lambda \eta \dot{\eta} \theta \varepsilon \iota \alpha$.

Pokud se chceme ptáti po bytnosti techniky, pak první odpověd' můžeme nacházet zde - technika je svojí bytností tím, co nám zpřístupňuje $\alpha \lambda \eta \dot{\eta} \theta \varepsilon \iota \alpha$. Nikoli sama o sobě, ale vždy skrze interakci s naším Pobytem. Není to předmítnutá, apriorní danost, ale je tím, co se vynořuje v konkrétní situaci, do níž jsme vrženi a v níž můžeme techniku použít. Nepoužít techniku znamená umenšit své epistemické pole. Technika není pouhý prostředek, je jedním ze způsobů odkrývání $\alpha \lambda \eta ́ \theta \varepsilon \iota \alpha$ (Heidegger, 2004a, s. 13).

To je ale jen část úvahy o bytnosti techniky - $\tau \varepsilon \chi v \eta$ (tékhnē) původně ne-

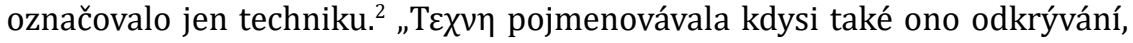
které do lesku toho, co se jeví, vynášelo pravdu (...) umění se jmenovalo pou-

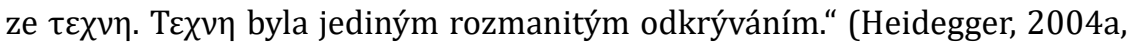
s. 33). Jinými slovy - není zde žádná ostrá hranice mezi vědou a uměním, mezi technikou v moderním slova smyslu a tím, co označujeme v řečtině jako

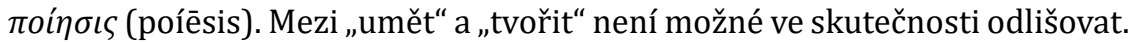
Technika nás tedy vede $\mathrm{k}$ hlubšímu promýšlení toho, co je $\mathrm{v}$ samém jádru vzdělávání. Je to nalézání neskrytosti, nikoli jako prostého faktu, pasivně anticipovaného, ale jako aktivního pohybu, který, pokud se děje, znamená nepřetržitou změnu toho, kdo poznává.

Dosáhli jsme určitého předběžného uchopení toho, co je to technika. Nyní musíme v úvahách reflektujících Heideggerovu myšlenku z titulku naší studie pokračovat. Co je to vzdálenost? (Heidegger, 1993, s. 7). Pro fenomenologii (a specificky pro Martina Heideggera) jsou čas a prostor jasně oddělené. Zatímco čas je něco, co se dotýká samého pramenu toho, kým jsme, naše bytí se nemůže dít jinak než v čase, tak prostor je něco méně blízkého. Je to prostor, který může ustoupit osobě, aby vytvořila skutečnou blízkost (Heidegger, 2004b). Tradičně se tento postulát ilustruje na př́kladu, že člověku může být blízký člověk, který je na druhé straně světa, ale soused mu může být zcela vzdálen. Jinými slovy - fenomenologie umožňuje rozlišovat vzdálenost,

2 Techniku původně jako postup, nikoliv jako předmět. 
prozatím zachycenou jako metrickou, a blízkost, v tomto případě jako otázku vztahovou.

Vzdálenost je vlastně míra rozprostraněnosti v prostoru. $V$ češtině máme slovo prostředí, které implikuje, že jde o něco mezi dvěma prvky. Tyto prvky, objekty, jsou oddělené od sebe prostřednictvím prostředí. Nijak na něm ale nezáleží, prostř̌edí je maximálně něčím, co může pohyb (interakci) objektů zpomalovat nebo umožňovat.

O Leukippově myšlení se ve spisu Vitae philosophorum $(\mathrm{A} 1,30)$ uvádí: „Tvrdil, že veškerenstvo je v sobě bezmezné a navzájem se proměňuje, že vše je prázdné a plné těles [atomů]. Světy vznikají, když tělesa [atomy] vpadají do prázdna a navzájem se proplétají. Z pohybu, který je následkem jejich přibývání, vzniká přirozenost hvězd." (Kratochvíl, 2009). To, co je zde důležité, je prostředí prázdna. Naopak všechny řecké koncepty pracující s pralátkou obsahují předpoklad, že to, co jest, vychází z nějakého společného základu.

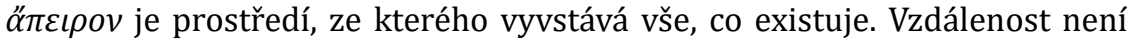
geometrický problém, ale je dána rozprostřeností v prostředí. Německé slovo Umwelt jasně odkazuje ke skutečnosti, že prostředí není něčím vnějším, něčím, co bychom měli poměřovat metrikou vně nás samotných, ale jde

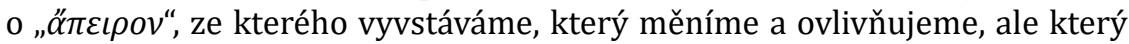
současně konstituuje nás. Nejde o něco, co je mezi anonymními objekty, ale je substrátem umožňujícím existenci věcí.

Odbočka k řeckému myšlení nebyla náhodná - překonat vzdálenost totiž neznamená jen zkrátit metriku, podobně jako když budeme metrickým prostorem transformovat velikost vektoru $\mathrm{v}$ prostoru. Zkrácení vzdálenosti je něčím mnohem hlubším a závažnějším. Je-li Umwelt tím, z čeho vyvstává náš Pobyt (Dasein), pak změna jeho struktury a rozprostřenosti, změny vzdáleností v něm, to že je nahuštován a zaplňován, mění to, kým jsme.

$T \varepsilon \chi v \eta$ je vynášením věcí na světlo, činní neskrytým to, co bylo skryté. Ale tato $\alpha \lambda \eta \dot{\theta \varepsilon \iota \alpha}$ je aktivně konstituována. To znamená, že prostřednictvím techniky přetváŕíme nejen prostředí, ve kterém žijeme, ale celý prostor, ze kterého vyvstáváme. To nás přivádí $\mathrm{k}$ novému promyšlení celé edukační skutečnosti. Edukace neprobíhá v prázdnu (schole), ale je činností ve světě, je něčím, co pomáhá jedinci konstituovat sebe sama v prostředí, ve kterém se nachází. Toto pragmatistické pojetí, které je patrné například v pracích George Lakoffa (2006), dává pohlédnout do smyslu toho, o co nám ve vzdělávání jde. 
Diskuse ohledně výstupů z učení, vzdělávacích cílů či kurikulárních reforem je něčím, co je do značné míry technikou v tom naivním slova smyslu, o kterém jsme hovořili na počátku naší studie. Vede k pojetí, které, jak zdůrazňuje Heidegger, se se skutečným uchopením techniky, s otázkou po její bytnosti, tedy tom jak mění naše bytí, míjí. Tyto úvahy nám tedy umožňují jít hlouběji a dále.

Naše pojetí prostředí je jiné než Leukippovo - domníváme se, že atomistická představa izolovaných elementů vznášejících se v prázdnu není vhodná. Východisko bychom mnohem spíše mohli označit jako ekologické. Proto bude prvořadým úkolem zkusit promyslet, co se v kontextu techniky děje s prostředím, ve kterém žijeme. Již však nikoliv techniky jako verba, ale jako substantiva, jako zhmotnění onoho postupu do arteficiální podoby.

Luciano Floridi v této souvislosti hovoří o tom, že vhodným způsobem pro popis prostředí je pojem infosféry:

ICT [informační a komunikační technologie] modifikují samotnou podstatu skutečnosti, a tím i to, co máme na mysli realitou, tím, že ji přeměňují v infosféru. Infosféra je neologismus vytvořený v sedmdesátých letech. Je založen na „biosféře“, což je termín odkazující na tento omezený prostor naší planety, který podporuje život. Je to také koncept, který se rychle vyvíjí. Infosféra minimálně označuje celé informační prostředí tvořené všemi informacemi; entity, jejich vlastnosti, interakce, procesy a vzájemné vztahy mezi nimi. Je to prostředí srovnatelné s kyberprostorem, které se však liší od kyberprostoru, což je pouze jedna z jeho podoblastí, protože infosféra zahrnuje i offline a analogové informační prostory. (Floridi, 2014 s. 40-41).

Umwelt, prostředí, do kterého jsme ponořeni, ale které nás také utváří, má významně informační charakter. Člověk není izolován od ostatních, je s nimi propojen skrze informační interakce. Ty přitom zakouší nejen s druhými lidmi, ale také s biotickými strukturami (např́íklad se zvíraty) nebo technikou. Prostředí, ve kterém žijeme, je skrze ICT zásadně jiné než to, ve kterém žily generace našich předků. Mění se charakter práce, existují pracovní týmy, které dohromady integrují systémy s umělou inteligencí a lidmi, spolupráce člověka se strojem je realitou od montážních závodů po nejnáročnější vědecké operace v biomedicíně. Technika nejen rozšírila epistemické pole, ale zásadně změnila téměř vše, co můžeme zkoumat. Tím, že má prostředí informační charakter, může docházet k jeho rychlým změnám. 
Pokud Heidegger hovoří o globalizaci, pak má na mysli právě toto - jsme schopni během několika desetin vteřiny přenést informaci $\mathrm{z}$ jednoho konce světa na druhý, změny infosféry $\mathrm{v}$ Japonsku se mohou $\mathrm{v}$ reálném čase promítat do infosféry primárně kotvené ve Spojených státech nebo u nás. Globalizace pokročila natolik, že jakýkoli koncept nacionalismu se zdá být zcela neudržitelný a nesmyslný (Šíp, 2019).

Technika zhroutila metriky. Slavný způsob, kterým Jan Amos Komenský tvoří mapy pomocí počítání otoček kola kočáru, způsob měření s pevnou metrikou, se rozpadá. Heidegger upozorňuje, že toto rozpadání měřítka, které můžeme někdy vnímat i jako rozpad hodnot, není špatné, spíše naopak. Naše bytí poměřujeme skrze měřítko, které ale nemůže být metrické, musí být transcendentální (Heidegger, 1993, s. 89). Jen tehdy, když neměřitelné, stále se měnící bytí nebude měřeno měřítky fixními, může být skutečně autentické, prožívající něco jiného než bytostnou šablonovitost, která se neumí a nechce skutečně ptát, nebot' je příliš zaneprázdněné obstaráváním věcí.

Toto zhroucení metriky můžeme v kontextu současné situace vidět všude kolem nás - na jedné straně pláč po tradiční rodině a tradičních hodnotách, na straně druhé výrazně zploštujuící se sociální stratifikace, kterou můžeme vidět na sociálních sítích. Vznik „alternativního“ vzdělávání na straně jedné, na straně druhé je jedna $\mathrm{z}$ největších obav v době pandemie covid-19 jak klasifikovat žáky. To, co bylo vnímané jako pevné a neměnné, se zdá být dekonstruováno. Otázka po měřítku, vztaženému k Pobytu v novém, měnícím se prostředí, je jednou z klíčových výzev dneška od sociologie po pedagogiku.

Floridi upozorňuje, že tyto ostré hranice mezi pojmy, pevná měřítka, mizí, hranice mezi konstrukty entit se postupně rozmývají (Floridi, 2015, s. 9). Pokud bychom chtěli v tomto poznatku spatřovat důvod pro to, že by bylo vhodné promýšlet integraci předmětů do širších celků, jistě bychom se nedopustili desinterpretace. Je to ICT, která mění to, co je důležité umět. Soutěže jako Chcete být milionářem nebo Riskuj, které byly populární až do poloviny desátých let minulého století, dnes již nemohou nikoho zaujmout - lepších výsledků než nejlepší soutěžící v nich snadno dosáhne žák deváté třídy s Wikipedií. Prostá znalost atomizovaných faktů se jeví jako zbytná, technika prohlubuje a zesiluje důraz kladený na souvislosti, na propojování znalostí do originálních celků, na to co technikou jako nástrojem ani jako postupem dokázat zatím neumíme. I běžná veřejnost vzala na vědomí skutečnost, že technika změnila koncept toho, co považujeme za vzdělanost nebo znalost. 
Vrat'me se ale ještě k našemu citátu - co tedy znamená, že technika překonala všechny vzdálenosti? Předně se stala nástrojem pro zjevování neskrytosti ukazující se na cestě. Vtáhla nás do situace, kdy pravda není předem dána, ale ukazuje se skrze naši aktivitu. To, co bylo dř́ve nedostupné, je nám nevzdálené, naše epistemické horizonty se zásadně rozšírily. Tato změna proměnila svět, ve kterém žijeme, prostředí, které poznáváme, ale i to, kým sami jsme. Jsme vrženi do situace, která se rychle mění, která je př́liš složitá a komplexní na to, abychom pro její zvládnutí mohli použít nějaký snadno dostupný prefabrikovaný postup, didaktickou poučku nebo př́klad dobré praxe.

Heidegger tedy tvrdí, že svět, ve kterém nyní žijeme, nás nutí myslet a ptát se nově, hlouběji, „nebot' tázání je zbožnost myšlení“ (Heidegger, 2004a, s. 35). Technika a překonání vzdáleností otevírají tedy nový prostor pro tázání. Tázání se, ona pečlivost v otázce, která je typická pro dílo německého filosofa, může být pozvánkou do uchopení pedagogiky stojící na důrazu na myšlení.

Nyní ale musíme přistoupit k druhé části citátu - co je „nepřinesená blízkost“? Slovo přinést znamená vzít s sebou. Slovo ố $\gamma \omega$ znamená vést či doprovázet, přinést je tedy činnost blízká pedagogice i technice. Znamená vzít s sebou, nikoli ve smyslu nákladu, ale samé povahy činnosti. Znamená neodlučitelnou složku určitého konání. Pedagogika jako $\pi \alpha \iota \delta \alpha \gamma \omega \gamma \varepsilon ́ \omega$ (paidagōgéō) také není „vláčením dítěte“, jako by bylo příručním jsoucnem, ale jeho nejvlastnějším přibráním $\mathrm{k}$ cestě. $\mathrm{K}$ cestě, po níž se nelze vydávat jinak než společně.

Je tedy snadné nahlédnout, co znamená přinášet blízkost - znamená to být s druhým na cestě. Toto bytí s druhým ale může mít podle Martina Bubera dvě odlišné formy (Buber, 2005). Tou první je propozice Já-Ono; tato propozice člověka poutá ke světu, vede ho ke vztahu k druhému, jako k věci. Je přitom něčím, co zažíváme po většinu času - není něčím špatným, druhého vidí jako prvek s vlastnostmi, které je možné měnit a rozvíjet. Popisuje ho jako prvek s atributy. Toto pojetí je vždy v blízkosti přítomné, učitel se mu nemůže vymanit a jeho vlastní práce je často zaměřená právě na tuto složku propozičního vztahu.

Propozice Já-Ty je typická pro vztah - druhý zde není viděn, dle Bubera, jako entita s vlastnostmi, ale jako ten, který je, jako hlubina jeho vlastního já. Ostatně když se Hospodin představuje Mojžíšovi, ř́ká: „Já jsem, který jsem“ (Ex 3,14), tedy není ničím s př́padky, vztah ve své autenticitě musí překročit hloubku povrchové deskripce a zasáhnout hlubinu nejvlastnějšího bytí 
druhého. Velice podobně hovoří Heidegger, který užívá konceptu Mitsein, tedy spolubytí, jako jednoho z důležitých prvků konstituce Pobytu (Heidegger, 2018, s. 154). Bez Mitsein není Dasein. ${ }^{3}$ Osoba je konstituována vztahy, propozicemi, jak uvádí Buber.

Pokud se tedy ptáme, co to znamená přinášet blízkost, pak jde o akt spolubytí s druhým, nikoli jako volný občasný akt, ale jako zaměření podstaty vlastní činnosti. Cílem pedagogiky musí být právě Mitsein, občasné, vzácné, ale přesto systematicky budované spojení Já-Ty. Jen skrze ně se dotýkáme druhého jako člověka, plníme nejvlastnější úkol vzdělávání.

Jak tedy chápat větu, že „technika překonala všechny vzdálenosti, avšak nevytvořila žádnou blízkost"? Domníváme se, že jako zásadní pedagogický úkol. Skrze techniku jsme více než kdy jindy mohli vzdělání skutečně přiblížit prostředí, ve kterém studenti žijí, akcentovat vzdělávání jako prožitek situace. Chápat techniku jako způsob aktivního přinášení neskrytosti. Technika ale sama o sobě nesporně propozici Já-Ty nezajistí. Stojíme před výzvou, v níž spatřujeme měnící se Umwelt edukační reality i Dasein učitele, stejně jako studenta. Výzvou, která se ptá, jak v takové situaci přinést blízkost.

Pandemie, kterou jsme prožívali v první polovině roku 2020, nesporně oba klíčové pojmy proměnila, transformovala i to, čemu ř́káme technika. Ale nijak nesnížila význam blízkosti. Zpráva Osborna a Freye (2017), která analyzovala ohroženost jednotlivých pracovních pozic v souvislosti s technologickými změnami, zařadila učitele na místa, která jsou ohrožena zdaleka nejméně. Nikoliv proto, že by zde nebyly nástroje, jak naučit počty nebo vyjmenovaná slova a data skrze ICT, avšak proto, že esencí profesní identity učitele je vztahovost. Učitel je ten, který pomáhá druhému učinit se - stát se někým. A to není možné bez zakoušeného vztahu.

Věta „technika překonala všechny vzdálenosti, avšak nevytvořila žádnou blízkost" není povzdechem nad technikou, ale výzvou k tomu, abychom se dokázali v edukačním prostředí ptát a současně nacházeli blízkost $\mathrm{s}$ těmi, kteří do společného sdíleného světa vstupují s námi. Technika tomu nesporně není na překážku.

Heidegger (2018, s. 154) doslova píše: „K spolubytí patřící odemčenost spolupobytu druhých znamená: poněvadž bytí pobytu je spolubytí, je v jeho porozumění bytí obsaženo porozumění druhým. Toto porozumění, tak jako porozumění vůbec, není nějaká znalost vyrůstající z poznání, nýbrž původní existenciální způsob bytí.“ 


\section{Literatura}

Arendt, H. (1996). Původ totalitarismu I-III. Praha: Oikoymenh.

Arendt, H. (2009). Vita activa neboli O činném životě. Praha: Oikoymenh.

Buber, M. (2005). Já a Ty. Praha: Kalich.

Floridi, L. (2014). The fourth revolution: How the infosphere is reshaping human reality. Oxford: Oxford University Press.

Floridi, L. (2015). The onlife manifesto: Being human in a hyperconnected era. London: Springer.

Frey, C. B., \& Osborne, M. A. (2017). The future of employment: How susceptible are jobs to computerisation? Technological forecasting and social change, 114, 254-280.

Heidegger, M., \& Beaufret, J. (1949). Über den humanismus. Frankfurt am Main: Klostermann.

Heidegger, M. (1993). Básnicky bydlí člověk. Praha: Oikoymenh.

Heidegger, M. (2004a). Věda, technika a zamyšlení. Praha: Oikoymenh.

Heidegger, M. (2004b). Kant a problém metafyziky. Praha: Filosofia.

Heidegger, M. (2018). Bytí a čas. Praha: Oikoymenh.

Kratochvíl, Z. (2009). Leukippos Fragmenta DK 67 A. Fysis. Dostupné z http://www.fysis.cz/ presokratici/leukippos/67a.htm

Lakoff, G. (2006). Ženy, oheň a nebezpečné věci: co kategorie vypovídají o naší mysli. Triáda.

Palouš, R. (2008). Heretická škola: o filosofii výchovy ve světověku a Patočkově pedagogice čili filipika proti upadlé škole. Praha: Oikoymenh.

Šíp, R. (2019). Proč školství a jeho aktéři selhávají: Kognitivní krajiny a nacionalismus. Brno: Masarykova univerzita.

\section{Autor}

RNDr. Michal Černý, Masarykova univerzita, Pedagogická fakulta, Katedra sociální pedagogiky, Poříčí 7, 60300 Brno, e-mail: cernymichal@mail.muni.cz 